\title{
Statins in cardiometabolic disease: what makes pitavastatin different?
}

\author{
Henry Ginsberg*
}

\begin{abstract}
The term cardiometabolic disease encompasses a range of lifestyle-related conditions, including Metabolic syndrome (MetS) and type 2 diabetes (T2D), that are characterized by different combinations of cardiovascular (CV) risk factors, including dyslipidemia, abdominal obesity, hypertension, hyperglycemia/insulin resistance, and vascular inflammation. These risk factors individually and interdependently increase the risk of CV and cerebrovascular events, and represent one of the biggest health challenges worldwide today. CV diseases account for almost $50 \%$ of all deaths in Europe and around 30\% of all deaths worldwide. Furthermore, the risk of CV death is increased twofold to fourfold in people with T2D. Whilst the clinical management of CV disease has improved in Western Europe, the pandemic of obesity and T2D reduces the impact of these gains. This, together with the growing, aging population, means the number of CV deaths is predicted to increase from 17.1 million worldwide in 2004 to 23.6 million in 2030. The recommended treatment for MetS is lifestyle change followed by treatment for the individual risk factors. Numerous studies have shown that lowering low-density lipoprotein-cholesterol (LDL-C) levels using statins can significantly reduce CV risk in people with and without T2D or MetS. However, the risk of major vascular events in those attaining the maximum levels of LDL-C-reduction is only reduced by around one-third, which leaves substantial residual risk. Recent studies suggest that low high-density lipoprotein-cholesterol (HDL-C) $(<1.0 \mathrm{mmol} / \mathrm{l}$; $40 \mathrm{mg} / \mathrm{dl}$ ) and high triglyceride levels ( $\geq 1.7 \mathrm{mmol} / \mathrm{l} ; 150 \mathrm{mg} / \mathrm{dl}$ ) are independent risk factors for $\mathrm{CV}$ disease and that the relationship between $\mathrm{HDL}-\mathrm{C}$ and $\mathrm{CV}$ risk persists even when on-treatment $\mathrm{LDL}-\mathrm{C}$ levels are low $(<1.7 \mathrm{mmol} / \mathrm{l}$; $70 \mathrm{mg} / \mathrm{dl}$ ). European guidelines highlight the importance of reducing residual risk by targeting these risk factors in addition to LDL-C. This is particularly important in patients with T2D and MetS because obesity and high levels of glycated hemoglobin are directly related to low levels of $\mathrm{HDL}-\mathrm{C}$ and high triglyceride. Although most statins have a similar low-density lipoprotein-lowering efficacy, differences in chemical structure and pharmacokinetic profile can lead to variations in pleiotropic effects (for example, high-density lipoprotein-elevating efficacy), adverse event profiles, and drug-drug interactions. The choice of statin should therefore depend on the needs of the individual patient. The following reviews will discuss the potential benefits of pitavastatin versus other statins in the treatment of patients with dyslipidemia and MetS or T2D, focusing on its effects on HDL-C quantity and quality, its potential impact on atherosclerosis and $\mathrm{CV}$ risk, and its metabolic characteristics that reduce the risk of drug interactions. Recent controversies surrounding the potentially diabetogenic effects of statins will also be discussed.
\end{abstract}

\section{Introduction}

According to the World Health Organization, 63\% of the 57 million deaths in 2008 were due to noncommunicable diseases [1]. Of these, cardiovascular (CV) diseases were the most common, accounting for approximately $30 \%$ of all deaths globally, followed by cancers (13\%), chronic lung diseases (7\%) and diabetes (2\%). Whilst noncommunicable disease mortality rates have fallen in the

*Correspondence: hng1@columbia.edu

Irving Institute for Clinical and Translational Research, Columbia University Medical Center, 622 West $168^{\text {th }}$ Street, New York, NY 10032, USA developed world during recent years, rates continue to increase in lower income populations, with approximately $80 \%$ of all noncommunicable disease deaths occurring in low-income and middle-income countries. Of these deaths, $29 \%$ occur in people under the age of 60 years.

Of the 17.3 million CV deaths in 2008, 7.3 million were due to coronary heart disease and 6.2 million were due to stroke [2]. Major modifiable risk factors for CV disease and other noncommunicable diseases include hypertension, dyslipidemia, tobacco use, low fruit-vegetable intake, alcohol use, physical inactivity and high body 
mass index. Rather than existing in isolation, these risk factors tend to occur in clusters [3]. Data from the National Health and Nutrition Examination Survey (1999 to 2000 ) showed that $93.1 \%, 73.0 \%$, and $35.9 \%$ of US adults had $\geq 1, \geq 2$, and $\geq 3$ modifiable risk factors for $\mathrm{CV}$ disease, respectively [4]. Since each additional risk factor has a multiplicative, rather than an additive, effect on vascular risk [5], patients with clusters of risk factors have a significantly increased risk of developing $\mathrm{CV}$ and cerebrovascular disease. Metabolic syndrome (MetS), for example - characterized by three or more of the following: abdominal obesity, atherogenic dyslipidemia, hypertension, and/or insulin resistance with or without glucose intolerance [6-10] - is associated with a twofold to fourfold increased risk of stroke, a threefold to fourfold increased risk of myocardial infarction [11,12], and a fivefold to ninefold higher risk of developing type 2 diabetes (T2D) [13]. Similarly, T2D is associated with a twofold to fourfold increased risk of CV death [14]. Given that many $\mathrm{CV}$ risk factors are silent, patients with individual risk factors should be assessed for their overall cardiometabolic profile and treated accordingly.

The recommended treatment for MetS is lifestyle change, focusing on weight loss and physical activity, followed by pharmaceutical treatment for the individual risk factors [6,8-10]. Dyslipidemia - an imbalance between the proatherogenic apolipoprotein-B-containing lipoproteins (low-density lipoproteins, very-low density lipoproteins and chylomicrons/chylomicron remnants) and anti-atherogenic high-density lipoproteins (HDLs) is a major risk factor for $\mathrm{CV}$ and cerebrovascular disease $[5,15]$. Numerous studies show that lowering low-density lipoprotein-cholesterol (LDL-C) levels using statins can significantly reduce $\mathrm{CV}$ risk in people with and without T2D, with no lower limit beyond which LDL-C-lowering is not beneficial [16-23]. Based on these results, most international treatment guidelines recommend lowering LDL-C to $<2.6 \mathrm{mmol} / \mathrm{l}(100 \mathrm{mg} / \mathrm{dl})$ in patients with established CV disease and to $<1.8$ to $2.0 \mathrm{mmol} / 1$ (70 to $80 \mathrm{mg} / \mathrm{dl}$ ) in those with very high CV risk, reducing total cholesterol to $<4.5 \mathrm{mmol} / \mathrm{l}(174 \mathrm{mg} / \mathrm{dl})$ with an option of $<4 \mathrm{mmol} / \mathrm{l}(154 \mathrm{mg} / \mathrm{dl})$ if feasible [6,9,24-26]. Although most statins (including atorvastatin, simvastatin and pitavastatin) have similar effects on LDL-C levels [27-37], differences in chemical structure and pharmacokinetic profile can lead to variations in pleiotropic effects, adverse event profiles and drug-drug interactions. The choice of statin should therefore depend on the characteristics and needs of the individual patient.

Despite the widespread availability of effective lipidlowering drugs, the prevalence of hypercholesterolemia varies considerably throughout Europe, ranging from 3 to $53 \%$ in men and from 4 to $40 \%$ in women, depending on the country [38]. In most populations, almost $50 \%$ of people treated with lipid-lowering drugs have a total cholesterol level $>6.5 \mathrm{mmol} / \mathrm{l}(251 \mathrm{mg} / \mathrm{dl})$, suggesting that greater efforts are needed to identify and adequately treat people with hypercholesterolemia. Moreover, even in patients that fully attain their total cholesterol/LDL-C targets, the risk of major vascular events is only reduced by around one-third [17], leaving substantial residual risk. The identification and treatment of residual risk factors is therefore essential for the effective management of CV disease.

\section{The importance of high-density lipoprotein for reducing residual risk}

Numerous studies have shown that low levels of highdensity lipoprotein-cholesterol (HDL-C) (defined as $<1 \mathrm{mmol} / \mathrm{l} ; 40 \mathrm{mg} / \mathrm{dl}$ in men, and $<1.3 \mathrm{mmol} / \mathrm{l} ; 50 \mathrm{mg} / \mathrm{dl}$ in women) are independent risk factors for coronary heart disease [39-46]. The Emerging Risk Factors Collaboration analyzed records from 68 studies in 302,430 people without initial vascular disease and demonstrated that each $0.38 \mathrm{mmol} / \mathrm{l}(14 \mathrm{mg} / \mathrm{dl})$ increase in HDL-C level was associated with a $22 \%$ reduction in coronary heart disease risk, irrespective of the triglyceride (TG) level (Figure 1) [42]. Consequently, the recent European Society of Cardiology/European Atherosclerosis Society Guidelines for the Management of Dyslipidemia have included low HDL-C levels in their latest CV risk assessment charts $[6,9,39]$. This is particularly important for people with MetS or T2D who often have low levels of HDL-C accompanied by high levels of TG $(\geq 1.7 \mathrm{mmol} / \mathrm{l}$; $150 \mathrm{mg} / \mathrm{dl}$ ) and a preponderance of small, dense lowdensity lipoprotein particles that can result in an underestimation of risk based solely on LDL-C. This triad of lipid abnormalities has been called atherogenic dyslipidemia [47-49].

A number of therapeutic options are available for increasing HDL-C levels, including statins, fibrates and niacin $[6,39]$. In general, niacin can increase HDL-C by 10 to $25 \%$. However, recent results from the AIM-HIGH and HPS-2 THRIVE studies showed that the additional increases in HDL-C achieved when extended-release niacin was added to a statin did not result in further reductions in CV events $[50,51]$. Fibrates, on the contrary, can increase HDL levels by 2 to $10 \%$ and have been shown to reduce $\mathrm{CV}$ risk in people with significantly elevated levels of TG and reduced levels of HDL-C [52-55]. For example, the Action to Control Cardiovascular Risk in Diabetes (ACCORD) study found that the primary event rate (a composite of nonfatal myocardial infarction, stroke or CV death) was reduced from $17.3 \%$ to $12.4 \%$ in the subgroup of $\mathrm{T} 2 \mathrm{D}$ patients with both low baseline levels of HDL-C $(\leq 34 \mathrm{mg} / \mathrm{dl}$ or $0.88 \mathrm{~mol} / \mathrm{l})$ and high baseline TG $(\geq 204 \mathrm{mg} / \mathrm{dl}$ or $\geq 2.3 \mathrm{mmol} / \mathrm{l}$ ) [52]. However, this study also showed that 


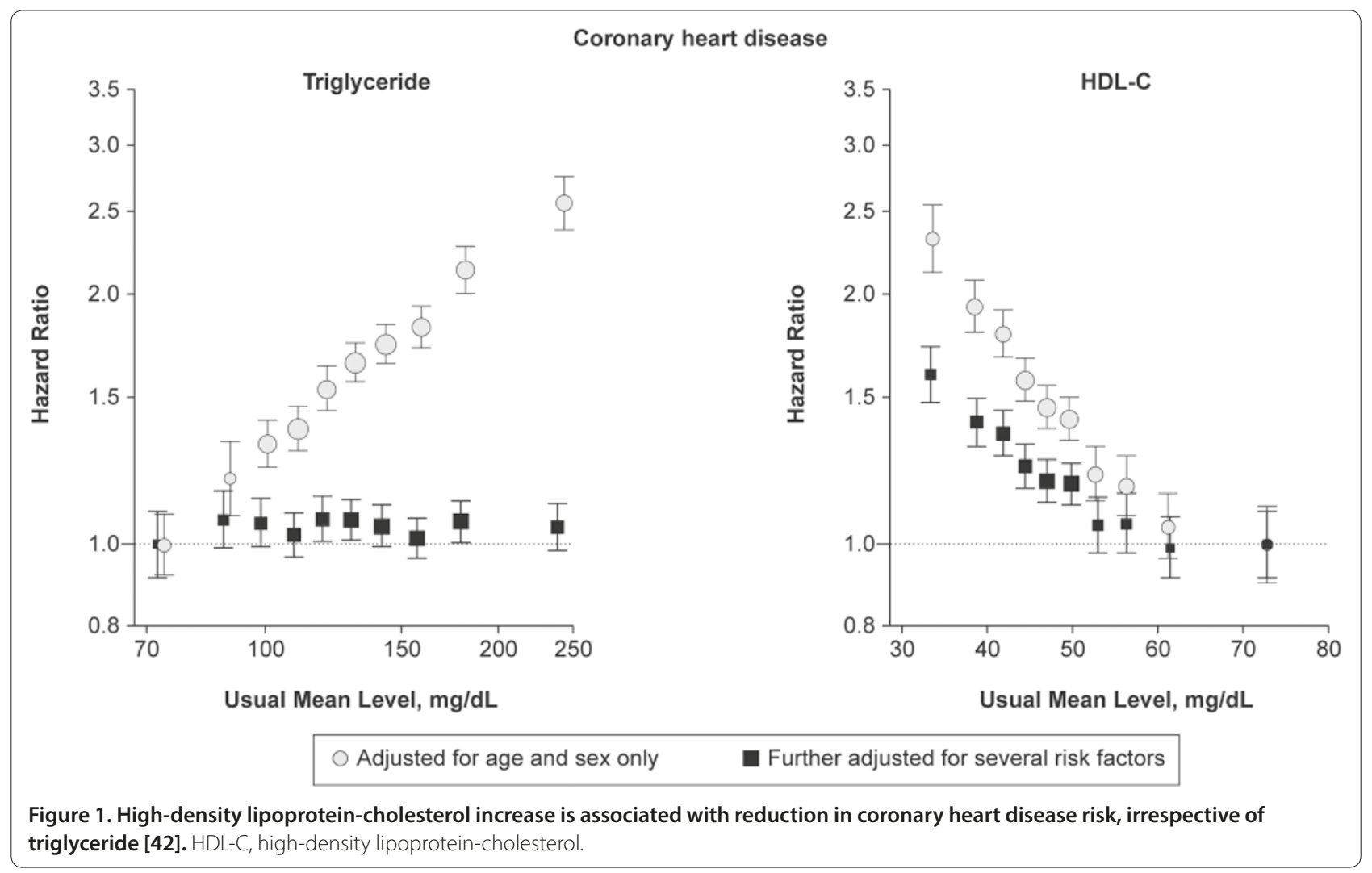

the addition of fenofibrate to conventional statin treatment had no effect on event rates in people with normal levels of TG and/or HDL-C.

To date, the only lipid-lowering studies in which druginduced elevations in HDL-C have been found to correlate with reductions in $\mathrm{CV}$ risk involve statins [56-60]. A post hoc analysis of the Treating to New Targets (TNT) trial conducted in 2,661 subjects achieving LDL-C $<1.8 \mathrm{mmol} / \mathrm{l}(70 \mathrm{mg} / \mathrm{dl})$ during treatment with atorvastatin 10 or $80 \mathrm{mg} /$ day showed that HDL-C levels were predictive of major $\mathrm{CV}$ events across the entire cohort, both when HDL-C was considered a continuous variable and when subjects were stratified according to HDL-C quintile [56]. This relationship remained true even after event rates were adjusted for other risk factors, including baseline levels of LDL-C (Figure 2).

Consistent with this observation, a post hoc analysis of intravascular ultrasound data from 1,455 people in four prospective randomized clinical trials showed that statinassociated changes in HDL-C were inversely associated with the progression of coronary atherosclerosis even in patients with low levels of LDL-C [61]. The proposed explanation for these findings is that statin-induced HDL elevations stimulate the 'reverse cholesterol transport' pathway, a process in which excess cholesterol is removed from peripheral cells and transported to the liver via HDL for excretion into bile [49]. Although most statins increase HDL-C levels to some extent, pitavastatin consistently produces significantly greater HDL elevations that are maintained, or increased, over time $[29,58,60,62-64]$. Pitavastatin is therefore likely to be particularly efficacious in people with low levels of HDL-C, such as those with cardiometabolic disease.

In addition to their role in cholesterol homeostasis, HDL particles have been shown to reduce oxidation, reduce vascular inflammation and vascular thrombosis, to improve endothelial function and repair, and to regulate the function and survival of pancreatic $\beta$-cells $[47,49,65]$. These functions are often defective in patients with inflammatory conditions such as MetS and T2D and can add to a patient's overall CV risk. Recent studies have shown that, in addition to elevating HDL levels, some lipid-lowering agents are associated with pleiotropic effects that improve HDL structure and function [47,49,66-68]. This observation is supported by a recent study, in which pitavastatin was associated with significantly greater reductions in plaque volume per $1 \%$ increase in HDL-C than other statins (atorvastatin, pravastatin, rosuvastatin, simvastatin) [67]. Future studies should therefore assess the effects of statins on HDL quality as well as quantity.

The following reviews will discuss the potential benefits of pitavastatin versus other statins in the treatment of patients with dyslipidemia, MetS or T2D, focusing on its 


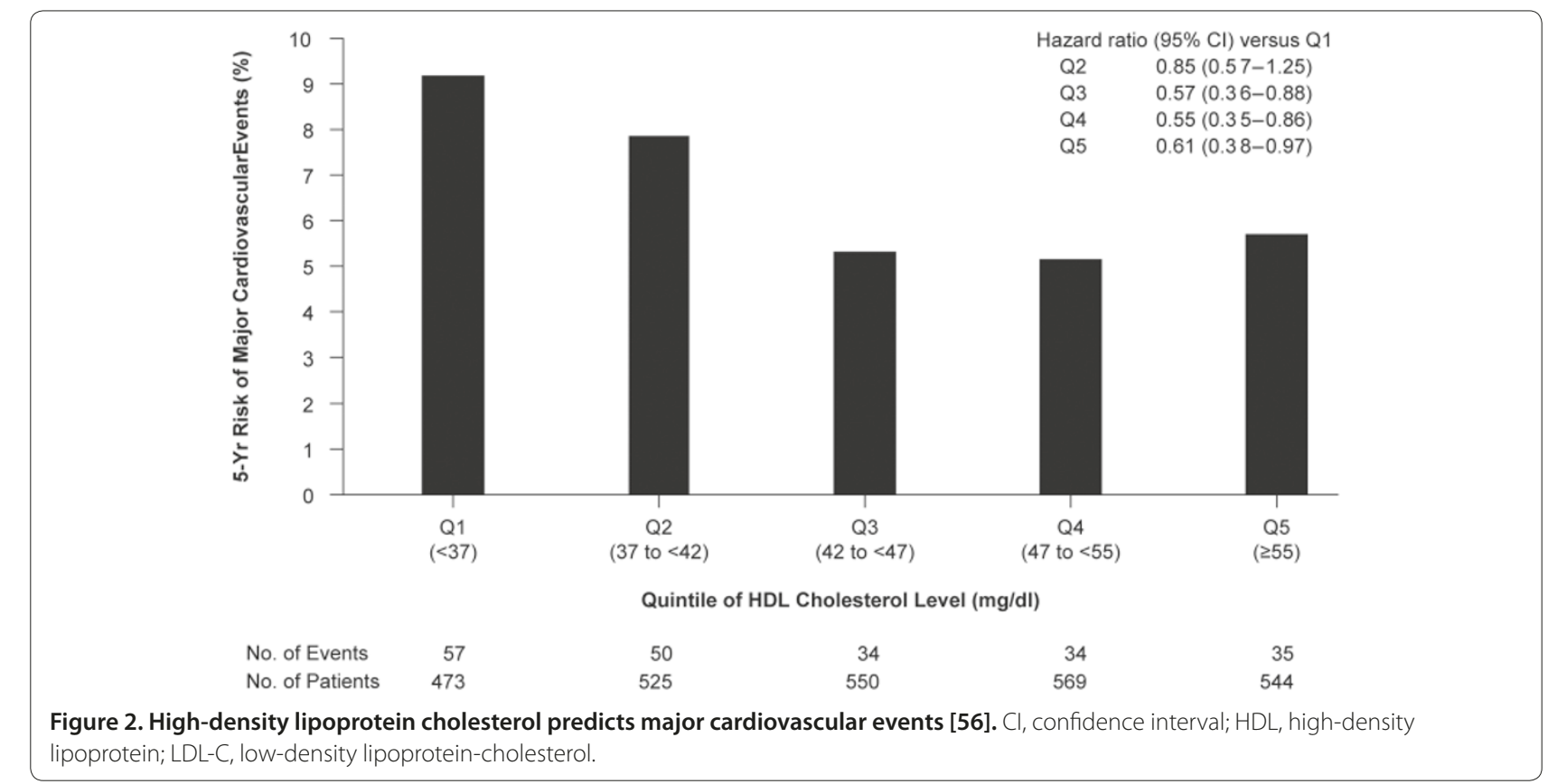

effects on HDL-C quantity and quality, its impact on atherosclerosis and $\mathrm{CV}$ risk, and the avoidance of drug interactions. Recent controversies surrounding the potentially diabetogenic effects of statins will also be discussed, with a focus on the possibility that pitavastatin differs positively from other statins in this regard.

\section{Abbreviations}

$\mathrm{CV}$, cardiovascular; $\mathrm{HDL}$, high-density lipoprotein; $\mathrm{HDL}-\mathrm{C}$, high-density lipoprotein-cholesterol; LDL-C, low-density lipoprotein-cholesterol; MetS, metabolic syndrome; T2D, type 2 diabetes; TG, triglyceride.

\section{Competing interests}

$\mathrm{HG}$ is a consultant for Kowa.

\section{Declaration}

This article has been published as part of Cardiovascular Diabetology Volume 12 Supplement 1, 2013: Statins in cardiometabolic disease: what makes pitavastatin different? The full contents of the supplement are available online at http://www.cardiab.com/supplements/12/S1. Publication of this supplement has been funded by Kowa Pharmaceutical Europe. Pitavastatin is a product marketed by the sponsor of the supplement. Articles are based on the proceedings of the World Congress for the Prevention of Diabetes. Authors received support with the preparation of their articles from GK Pharmacomm, an agency funded by the sponsor. All articles have undergone the journal's standard peer review process. The Supplement Editors declare that they have no competing interests.

Published: 30 May 2013

\section{References}

1. NCD Mortality and Morbidity.

[http://www.who.int/gho/ncd/mortality_morbidity/en/]

2. World Health Organization Cardiovascular Disease Statistics [http://www.who.int/mediacentre/factsheets/fs317/en/index.html]

3. Mancia G: Total cardiovascular risk: a new treatment concept. J Hypertens Supp/ 2006, 24:S17-S24.

4. Cohen JD, Cziraky MJ, Cai Q, Wallace A, Wasser T, Crouse JR, Jacobson TA: 30-year trends in serum lipids among United States adults: results from the National Health and Nutrition Examination Surveys II, III, and 19992006. Am J Cardio/ 2010, 106:969-975.

5. Yusuf S, Hawken S, Ounpuu S, Dans T, Avezum A, Lanas F, McQueen M, Budaj A, Pais P, Varigos J, Lisheng L: Effect of potentially modifiable risk factors associated with myocardial infarction in 52 countries (the INTERHEART study): case-control study. Lancet 2004, 364:937-952.

6. Reiner Z, Catapano AL, De BG, Graham I, Taskinen MR, Wiklund O, Agewall S, Alegria E, Chapman MJ, Durrington P, Erdine S, Halcox J, Hobbs R, Kjekshus J, Filardi PP, Riccardi G, Storey RF, Wood D, Bax J, Vahanian A, Auricchio A Baumgartner H, Ceconi C, Dean V, Deaton C, Fagard R, Filippatos G, FunckBrentano C, Hasdai D, Hobbs R, et al.: ESC/EAS Guidelines for the management of dyslipidaemias: The Task Force for the management of dyslipidaemias of the European Society of Cardiology (ESC) and the European Atherosclerosis Society (EAS). Eur Heart J 2011, 32:1769-1818.

7. Grundy SM, Cleeman JI, Daniels SR, Donato KA, Eckel RH, Franklin BA, Gordon DJ, Krauss RM, Savage PJ, Smith SC, Jr, Spertus JA, Fernando C: Diagnosis and management of the metabolic syndrome: an American Heart Association/ National Heart, Lung, and Blood Institute scientific statement: Executive Summary. Crit Pathw Cardiol 2005, 4:198-203.

8. International Diabetes Federation Consensus Worldwide Definition of the Metabolic Syndrome

[http://www.idf.org/webdata/docs/MetSyndrome_FINAL.pdf]

9. Perk J, De BG, Gohlke H, Graham I, Reiner Z, Verschuren WM, Albus C, Benlian P, Boysen G, Cifkova R, Deaton C, Ebrahim S, Fisher M, Germano G, Hobbs R, Hoes A, Karadeniz S, Mezzani A, Prescott E, Ryden L, Scherer M, Syvanne M, Op Reimer WJ, Vrints C, Wood D, Zamorano JL, Zannad F: European Guidelines on Cardiovascular Disease Prevention in Clinical Practice (Version 2012): The Fifth Joint Task Force of the European Society of Cardiology and Other Societies on Cardiovascular Disease Prevention in Clinical Practice (Constituted by Representatives of Nine Societies and by Invited Experts). Eur Heart J 2012, 33:1635-1701.

10. Definition, Diagnosis and Classification of Diabetes Mellitus and its Complications [http://www.who.int/diabetes/publications/en/]

11. Lakka HM, Laaksonen DE, Lakka TA, Niskanen LK, Kumpusalo E, Tuomilehto J, Salonen JT: The metabolic syndrome and total and cardiovascular disease mortality in middle-aged men. JAMA 2002, 288:2709-2716.

12. Ninomiya JK, L'Italien G, Criqui MH, Whyte JL, Gamst A, Chen RS: Association of the metabolic syndrome with history of myocardial infarction and stroke in the Third National Health and Nutrition Examination Survey. Circulation 2004, 109:42-46.

13. Laaksonen DE, Lakka HM, Niskanen LK, Kaplan GA, Salonen JT, Lakka TA: 
Metabolic syndrome and development of diabetes mellitus: application and validation of recently suggested definitions of the metabolic syndrome in a prospective cohort study. Am J Epidemiol 2002, 156:1070-1077.

14. World Health Organization Diabetes Statistics [http://www.who.int/mediacentre/factsheets/fs312/en/]

15. O'Donnell MJ, Xavier D, Liu L, Zhang H, Chin SL, Rao-Melacini P, Rangarajan S, Islam S, Pais P, McQueen MJ, Mondo C, Damasceno A, Lopez-Jaramillo P, Hankey GJ, Dans AL, Yusoff K, Truelsen T, Diener HC, Sacco RL, Ryglewicz D, Czlonkowska A, Weimar C, Wang X, Yusuf S: Risk factors for ischaemic and intracerebral haemorrhagic stroke in 22 countries (the INTERSTROKE study): a case-control study. Lancet 2010, 376:112-123.

16. LaRosa JC, Grundy SM, Waters DD, Shear C, Barter P, Fruchart JC, Gotto AM, Greten H, Kastelein JJ, Shepherd J, Wenger NK: Intensive lipid lowering with atorvastatin in patients with stable coronary disease. N Engl J Med 2005, 352:1425-1435

17. Baigent C, Blackwell L, Emberson J, Holland LE, Reith C, Bhala N, Peto R, Barnes EH, Keech A, Simes J, Collins R: Efficacy and safety of more intensive lowering of LDL cholesterol: a meta-analysis of data from 170,000 participants in 26 randomised trials. Lancet 2010, 376:1670-1681.

18. Kearney PM, Blackwell L, Collins R, Keech A, Simes J, Peto R, Armitage J, Baigent C: Efficacy of cholesterol-lowering therapy in 18,686 people with diabetes in 14 randomised trials of statins: a meta-analysis. Lancet 2008, 371:117-125.

19. Cannon CP, Steinberg BA, Murphy SA, Mega JL, Braunwald E: Meta-analysis of cardiovascular outcomes trials comparing intensive versus moderate statin therapy. J Am Coll Cardiol 2006, 48:438-445.

20. Wiviott SD, Cannon CP, Morrow DA, Ray KK, Pfeffer MA, Braunwald E: Can low-density lipoprotein be too low? The safety and efficacy of achieving very low low-density lipoprotein with intensive statin therapy: a PROVE IT-TIMI 22 substudy. J Am Coll Cardiol 2005, 46:1411-1416.

21. O'Keefe JH, Jr, Cordain L, Harris WH, Moe RM, Vogel R: Optimal low-density lipoprotein is 50 to $70 \mathrm{mg} / \mathrm{dl}$ : lower is better and physiologically normal. J Am Coll Cardiol 2004, 43:2142-2146.

22. 4S Study Group: Randomised trial of cholesterol lowering in 4444 patients with coronary heart disease: the Scandinavian Simvastatin Survival Study (4S). Lancet 1994, 344:1383-1389.

23. HPS STudy Group: MRC/BHF Heart Protection Study of cholesterol lowering with simvastatin in 20,536 high-risk individuals: a randomised placebo-controlled trial. Lancet 2002, 360:7-22.

24. Genest J, McPherson R, Frohlich J, Anderson T, Campbell N, Carpentier A, Couture P, Dufour R, Fodor G, Francis GA, Grover S, Gupta M, Hegele RA, Lau DC, Leiter L, Lewis GF, Lonn E, Mancini GB, Ng D, Pearson GJ, Sniderman A, Stone JA, Ur E: 2009 Canadian Cardiovascular Society/Canadian guidelines for the diagnosis and treatment of dyslipidemia and prevention of cardiovascular disease in the adult - 2009 recommendations. Can J Cardiol 2009, 25:567-579.

25. Third Report of the National Cholesterol Education Program (NCEP) Expert Panel on Detection, Evaluation, and Treatment of High Blood Cholesterol in Adults (Adult Treatment Panel III) final report. Circulation 2002 106:3143-3421.

26. Grundy SM, Cleeman Jl, Merz CN, Brewer HB, Jr, Clark LT, Hunninghake DB, Pasternak RC, Smith SC, Jr, Stone NJ: Implications of recent clinical trials for the National Cholesterol Education Program Adult Treatment Panel III Guidelines. J Am Coll Cardiol 2004 44:720-732.

27. Budinski D, Arneson V, Hounslow N, Gratsiansky N: Pitavastatin compared with atorvastatin in primary hypercholesterolemia or combined dyslipidemia. Clin Lipidol 2009, 4:291-302.

28. Ose L, Budinski D, Hounslow N, Arneson V: Comparison of pitavastatin with simvastatin in primary hypercholesterolaemia or combined dyslipidaemia. Curr Med Res Opin 2009, 25:2755-2764.

29. Ose L, Budinski D, Hounslow N, Arneson V: Long-term treatment with pitavastatin is effective and well tolerated by patients with primary hypercholesterolemia or combined dyslipidemia. Atherosclerosis 2010 210:202-208.

30. Yokote K, Bujo H, Hanaoka H, Shinomiya M, Mikami K, Miyashita Y, Nishikawa T, Kodama T, Tada N, Saito Y: Multicenter collaborative randomized parallel group comparative study of pitavastatin and atorvastatin in Japanese hypercholesterolemic patients: collaborative study on hypercholesterolemia drug intervention and their benefits for atherosclerosis prevention (CHIBA study). Atherosclerosis 2008, 201:345-352.
31. Sasaki J, Ikeda Y, Kuribayashi T, Kajiwara K, Biro S, Yamamoto K, Ageta M, Kobori S, Saikawa T, Otonari T, Kono S: A 52-week, randomized, open-label, parallel-group comparison of the tolerability and effects of pitavastatin and atorvastatin on high-density lipoprotein cholesterol levels and glucose metabolism in Japanese patients with elevated levels of lowdensity lipoprotein cholesterol and glucose intolerance. Clin Ther 2008, 30:1089-1101.

32. Eriksson M, Budinski D, Hounslow N: Comparative efficacy of pitavastatin and simvastatin in high-risk patients: a randomized controlled trial. Adv Ther 2011, 28:811-823.

33. Kimura $\mathrm{K}$, Shimano $\mathrm{H}$, Yokote $\mathrm{K}$, Urashima M, Teramoto $\mathrm{T}$ : Effects of pitavastatin (LIVALO tablet) on the estimated glomerular filtration rate (eGFR) in hypercholesterolemic patients with chronic kidney disease. Sub-analysis of the LIVALO Effectiveness and Safety (LIVES) Study. J Atheroscler Thromb 2010, 17:601-609.

34. Hiro T, Kimura T, Morimoto T, Miyauchi K, Nakagawa Y, Yamagishi M, Ozaki Y, Kimura K, Saito S, Yamaguchi T, Daida H, Matsuzaki M: Diabetes mellitus is a major negative determinant of coronary plaque regression during statin therapy in patients with acute coronary syndrome - serial intravascular ultrasound observations from the Japan Assessment of Pitavastatin and Atorvastatin in Acute Coronary Syndrome Trial (the JAPAN-ACS Trial). Circ J 2010, 74:1165-1174.

35. Hiro T, Kimura T, Morimoto T, Miyauchi K, Nakagawa Y, Yamagishi M, Ozaki Y, Kimura K, Saito S, Yamaguchi T, Daida H, Matsuzaki M: Effect of intensive statin therapy on regression of coronary atherosclerosis in patients with acute coronary syndrome: a multicenter randomized trial evaluated by volumetric intravascular ultrasound using pitavastatin versus atorvastatin (JAPAN-ACS [Japan assessment of pitavastatin and atorvastatin in acute coronary syndrome] study). J Am Coll Cardio/ 2009, 54:293-302.

36. Stender S, Hounslow N: Robust efficacy of pitavastatin and comparable safety to pravastatin. Atheroscler Suppl 2009, 10:P770.

37. Gumprecht J, Gosho M, Budinski D, Hounslow N: Comparative long-term efficacy and tolerability of pitavastatin $4 \mathrm{mg}$ and atorvastatin $20-40 \mathrm{mg}$ in patients with type 2 diabetes mellitus and combined (mixed) dyslipidaemia. Diabetes Obes Metab 2011, 13:1047-1055.

38. Tolonen H, Keil U, Ferrario M, Evans A: Prevalence, awareness and treatment of hypercholesterolaemia in 32 populations: results from the WHO MONICA Project. Int J Epidemiol 2005, 34:181-192.

39. Chapman MJ, Ginsberg HN, Amarenco P, Andreotti F, Boren J, Catapano AL, Descamps OS, Fisher E, Kovanen PT, Kuivenhoven JA, Lesnik P, Masana L, Nordestgaard BG, Ray KK, Reiner Z, Taskinen MR, Tokgozoglu L, TybjaergHansen A, Watts GF: Triglyceride-rich lipoproteins and high-density lipoprotein cholesterol in patients at high risk of cardiovascular disease: evidence and guidance for management. Eur Heart J 2011, 32:1345-1361.

40. Maron DJ: The epidemiology of low levels of high-density lipoprotein cholesterol in patients with and without coronary artery disease. Am Cardio/ 2000, 86:11L-14L.

41. Sharrett AR, Ballantyne CM, Coady SA, Heiss G, Sorlie PD, Catellier D, Patsch W: Coronary heart disease prediction from lipoprotein cholesterol levels, triglycerides, lipoprotein(a), apolipoproteins A-I and B, and HDL density subfractions: The Atherosclerosis Risk in Communities (ARIC) Study. Circulation 2001, 104:1108-1113.

42. Di Angelantonio E, Sarwar N, Perry P, Kaptoge S, Ray KK, Thompson A, Wood AM, Lewington S, Sattar N, Packard CJ, Collins R, Thompson SG, Danesh J: Major lipids, apolipoproteins, and risk of vascular disease. JAMA 2009, 302:1993-2000.

43. Assmann G, Schulte H, von EA: Hypertriglyceridemia and elevated lipoprotein(a) are risk factors for major coronary events in middle-aged men. Am J Cardiol 1996, 77:1179-1184.

44. Gordon T, Castelli WP, Hjortland MC, Kannel WB, Dawber TR: High density lipoprotein as a protective factor against coronary heart disease. The Framingham Study. Am J Med 1977, 62:707-714

45. Sviridov D, Nestel P, Watts G: Statins and metabolism of high density lipoprotein. Cardiovasc Hematol Agents Med Chem 2007, 5:215-221.

46. Gordon DJ, Probstfield JL, Garrison RJ, Neaton JD, Castelli WP, Knoke JD, Jacobs DR, Jr, Bangdiwala S, Tyroler HA: High-density lipoprotein cholesterol and cardiovascular disease. Four prospective American studies. Circulation 1989, 79:8-15.

47. Kontush A, Chapman MJ: Functionally defective high-density lipoprotein: a new therapeutic target at the crossroads of dyslipidemia, inflammation, and atherosclerosis. Pharmacol Rev 2006, 58:342-374. 
48. Nesto RW: Beyond low-density lipoprotein: addressing the atherogenic lipid triad in type 2 diabetes mellitus and the metabolic syndrome. Am J Cardiovasc Drugs 2005, 5:379-387.

49. Kontush A, Chapman MJ: Antiatherogenic small, dense HDL-guardian angel of the arterial wall? Nat Clin Pract Cardiovasc Med 2006, 3:144-153.

50. Boden WE, Probstfield $J$, Anderson T, Chaitman BR, Desvignes-Nickens P, Koprowicz K, McBride R, Teo K, Weintraub W: Niacin in patients with low HDL cholesterol levels receiving intensive statin therapy. N Engl J Med 2011 365:2255-2267.

51. Merck Announces HPS2-THRIVE Study of TREDAPTIVE ${ }^{\mathrm{TM}}$ (Extended Release Niacin/Laropiprant) Did Not Achieve Primary Endpoint [http://www.ctsu. ox.ac.uk/thrive/HPS2THRIVE\%20RELEASEUSWIREVERSIONfinal.pdf]

52. Ginsberg HN, Elam MB, Lovato LC, Crouse JR, III, Leiter LA, Linz P, Friedewald WT, Buse JB, Gerstein HC, Probstfield J, Grimm RH, Ismail-Beigi F, Bigger JT, Goff DC, Jr, Cushman WC, Simons-Morton DG, Byington RP: Effects of combination lipid therapy in type 2 diabetes mellitus. N Engl J Med 2010, 362:1563-1574.

53. Scott $R, O^{\prime}$ Brien $R$, Fulcher $G$, Pardy C, D'Emden M, Tse D, Taskinen MR, Ehnholm C, Keech A: Effects of fenofibrate treatment on cardiovascular disease risk in 9,795 individuals with type 2 diabetes and various components of the metabolic syndrome: the Fenofibrate Intervention and Event Lowering in Diabetes (FIELD) study. Diabetes Care 2009, 32:493-498.

54. Secondary prevention by raising HDL cholesterol and reducing triglycerides in patients with coronary artery disease: the Bezafibrate Infarction Prevention (BIP) study. Circulation 2000, 102:21-27.

55. Manninen $\mathrm{V}$, Tenkanen L, Koskinen P, Huttunen JK, Manttari M, Heinonen OP, Frick $\mathrm{MH}$ : Joint effects of serum triglyceride and LDL cholesterol and HDL cholesterol concentrations on coronary heart disease risk in the Helsinki Heart Study. Implications for treatment. Circulation 1992, 85:37-45.

56. Barter P, Gotto AM, LaRosa JC, Maroni J, Szarek M, Grundy SM, Kastelein JJ, Bittner $V$, Fruchart JC: HDL cholesterol, very low levels of LDL cholesterol, and cardiovascular events. N Engl J Med 2007, 357:1301-1310.

57. Matsuzaki M, Kita T, Mabuchi H, Matsuzawa Y, Nakaya N, Oikawa S, Saito Y, Sasaki J, Shimamoto K, Itakura H: Large scale cohort study of the relationship between serum cholesterol concentration and coronary events with low-dose simvastatin therapy in Japanese patients with hypercholesterolemia. Circ J 2002, 66:1087-1095.

58. Barter PJ, Brandrup-Wognsen G, Palmer MK, Nicholls SJ: Effect of statins on HDL-C: a complex process unrelated to changes in LDL-C: analysis of the VOYAGER Database. J Lipid Res 2010, 51:1546-1553.
59. Grover SA, Kaouache M, Joseph L, Barter P, Davignon J: Evaluating the incremental benefits of raising high-density lipoprotein cholesterol levels during lipid therapy after adjustment for the reductions in other blood lipid levels. Arch Intern Med 2009, 169:1775-1780.

60. Urashima M, Shimano H, Yokote K, Saito Y, Teramoto T: Association of highdensity lipoprotein cholesterol levels in pitavastatin treatment with risk of cardio-/cerebrovascular events in Japanese patients with dyslipidemia: analysis from the LIVES extension study [abstract]. J Am Coll Cardio/ 2011, 57:E520-E520.

61. Nicholls SJ, Tuzcu EM, Sipahi I, Grasso AW, Schoenhagen P, Hu T, Wolski K, Crowe T, Desai MY, Hazen SL, Kapadia SR, Nissen SE: Statins, high-density lipoprotein cholesterol, and regression of coronary atherosclerosis. JAMA 2007, 297:499-508.

62. Nicholls SJ, Brandrup-Wognsen G, Palmer M, Barter PJ: Meta-analysis of comparative efficacy of increasing dose of Atorvastatin versus Rosuvastatin versus Simvastatin on lowering levels of atherogenic lipids (from VOYAGER). Am J Cardiol 2010, 105:69-76.

63. Weng TC, Yang YH, Lin SJ, Tai SH: A systematic review and meta-analysis on the therapeutic equivalence of statins. J Clin Pharm Ther 2010, 35:139-151.

64. Teramoto T, Shimano H, Yokote K, Urashima M: Effects of pitavastatin (LIVALO Tablet) on high density lipoprotein cholesterol (HDL-C) in hypercholesterolemia. J Atheroscler Thromb 2009, 16:654-661.

65. von EA, Sibler RA: Possible contributions of lipoproteins and cholesterol to the pathogenesis of diabetes mellitus type 2. Curr Opin Lipidol 2011 22:26-32.

66. Khera AV, Cuchel M, Llera-Moya M, Rodrigues A, Burke MF, Jafri K, French BC, Phillips JA, Mucksavage ML, Wilensky RL, Mohler ER, Rothblat GH, Rader DJ: Cholesterol efflux capacity, high-density lipoprotein function, and atherosclerosis. N Engl J Med 2011, 364:127-135.

67. Kishida K, Funahashi T, Shimomura I: Importance of assessing the effect of statins on the function of high-density lipoproteins on coronary plaque. Cardiovasc Hematol Disord Drug Targets 2012, 12:28-34.

68. Kishida K, Funahashi T, Shimomura I: Effects of pitavastatin on HDL metabolism. Clin Lipidol 2013, 8:55-68.

doi:10.1186/1475-2840-12-S1-S1

Cite this article as: Ginsberg $\mathrm{H}$ : Statins in cardiometabolic disease: what makes pitavastatin different? Cardiovascular Diabetology 2013, 12(Suppl 1):S1. 